\title{
Cofnięcie rezygnacji z pełnionej funkcji przez marszałka województwa w świetle ustawy z dnia 5 czerwca 1998 r. o samorządzie województwa
}

\author{
Withdrawal of the resignation from the function of the voivodeship marshal \\ in the light of the Act of 5 June 1998 on voivodeship self-government \\ Отмена заявления об уходе в отставку маршалом воеводства в свете закона \\ от 5 июня 1998 года «О воеводском самоуправлении»
}

\author{
KATARZYNA KACZMARCZYK-KŁAK \\ Dr. hab., prof. Kujawsko-Pomorskiej Szkoły Wyższej w Bydgoszczy \\ e-mail: kkklak@interia.pl; https://orcid.org/0000-0001-6135-7677
}

\begin{abstract}
Streszczenie: W artykule przeprowadzono analizę możliwości cofnięcia rezygnacji przez marszałka województwa. Ustawa z dnia 5czerwca 1998 r. o samorządzie województwa wyraźnie stanowi, że marszałek województwa może złożyć rezygnację, ale nie reguluje wyraźnie instytucji cofnięcia takiego oświadczenia. Zdaniem autora nie oznacza to, że marszałek województwa nie może cofnąć oświadczenia o rezygnacji, albowiem nie wywołuje ono automatycznie żadnych skutków prawnych, w tym jego złożenie nie prowadzi do wygaśnięcia mandatu marszałka województwa. Do czasu głosowania przez sejmik województwa uchwały w przedmiocie przyjęcia rezygnacji marszałek województwa jest dysponentem złożonego przez sobie oświadczenia i może je wycofać. Za taką wykładnią przemawia konieczność zapewnienia marszałkowi województwa wolności wyboru i wykonywania zawodu oraz wyboru miejsca pracy, o której mowa w art. 65 ust. 1 Konstytucji RP z 2 kwietnia $1997 \mathrm{r}$.
\end{abstract}

Słowa kluczowe: marszałek województwa, rezygnacja marszałka województwa z pełnionej funkcji, cofnięcie rezygnacji przez marszałka województwa

Summary: The article analyses the possibility of the withdrawal of the resignation of the voivodeship marshal. The Act of 5 June 1998 on the self-government of a voivodeship explicitly states that a voivodeship marshal may resign, but does not expressly regulate the institution of withdrawing such a declaration. In the author's opinion, this does not mean that the voivodeship marshal cannot withdraw their resignation statement, because it does not automatically cause any legal effects, including the fact that its submission does not lead to the expiry of the voivodeship marshal's mandate. Until the voivodeship parliament votes, a resolution on accepting the resignation is the disposable marshal of the voivodeship's own declaration and they may withdraw it. This interpretation is argued by the need to ensure that the voivodeship marshal has the freedom to choose and practice their profession, as well as to choose their place of work, as referred to in art. 65 section 1 of the Polish Constitution of 2 April 1997.

Key words: voivodeship marshal, resignation of the voivodeship marshal, resignation, acceptance of resignation

Резюме: В статье анализируется возможность отмены заявления об уходе в отставку маршалом воеводства. Закон от 5 июня 1998 года «О воеводском самоуправлении» четко устанавливает, что маршал воеводства может подать заявление об уходе в отставку, но не регламентирует четко института отмены такого заявления. По мнению автора, это не означает, что маршал воеводства не может отозвать свое заявление об отставке, поскольку это не влечет за собой автоматически никаких юридических последствий, в том числе не приводит к истечению срока полномочий маршала воеводства. Пока воеводский сеймик не проголосует за отставку, маршал воеводства является держателем поданного им заявления 
и может его отозвать. Такое толкование подкрепляется необходимостью обеспечить маршалу воеводства свободу выбора профессии и профессиональной деятельности, а также выбора места работы, как это предусмотрено ст. 65 п. 1 Конституции Польши от 2 апреля 1997 года.

Ключевые слова: маршал воеводства, уход в отставку маршала воеводства, отзыв заявления об уходе в отставку маршалом воеводства

Zgodniez ustawą z dnia 5 czerwca 1998 r.o samorządzie województwa ${ }^{1}$ (dalej:u.s.w.) „W przypadku złożenia rezygnacji przez marszałka województwa jej przyjęcie następuje zwykłą większością głosów" (art. 38 ust. 1). Ustawa uregulowała zatem instytucję złożenia rezygnacji przez marszałka województwa, wyraźnie dopuszczając taką możliwość, jak też przyjęła, że samo złożenie oświadczenia w przedmiocie rezygnacji nie wywołuje skutku w postaci wygaśnięcia mandatu marszałka województwa. Rezygnacja marszałka województwa musi być przyjęta przez sejmik województwa, co następuje zwykłą większością głosów (art. 38 ust. 1 in fine u.s.w.). W przypadku rezygnacji marszałka województwa sejmik województwa na najbliższej sesji podejmuje uchwałę o przyjęciu rezygnacji całego zarządu (art. 38 ust. 2 u.s.w.). Niepodjęcie uchwały, o której mowa w art. 38 ust. 2 u.s.w., jest równoznaczne z przyjęciem rezygnacji z upływem ostatniego dnia miesiąca, w którym odbyła się sesja sejmiku, o której mowa w tym przepisie (art. 38 ust. 3 u.s.w.). Brzmienie art. 38 u.s.w. skłania do sformułowania pytania, czy dopuszczalne jest cofnięcie rezygnacji złożonej przez marszałka województwa na podstawie art. 38 ust. 1 u.s.w.? Jest to problem nie tylko teoretyczny, ale także praktyczny, w lutym 2019 r. marszałek województwa podlaskiego złożył bowiem rezygnację², a następnie cofnął swoje oświadczenie o rezygnacji z pełnionej funkcji, co wywołało szereg wątpliwości interpretacyjnych, zarówno dotyczących samej możliwości cofnięcia złożonej rezygnacji, jak i trybu procedowania - w takim przypadku - sejmiku województwa. Co istotne, w piśmiennictwie problematyka zarówno złożenia rezygnacji przez marszałka województwa, jak i możliwości jej cofnięcia nie spotkała się dotąd z szerszą refleksją naukową, warto zatem dokonać analizy obowiązujących przepisów celem udzielania odpowiedzi na sformułowane powyżej pytanie. Wyrażam pogląd, że marszałek województwa może cofnąć rezygnację złożoną na podstawie art. 38 ust. 1 u.s.w.

Jak trafnie wskazano w piśmiennictwie, treść art. 38 ust. 2 u.s.w. wskazuje, że sejmik województwa winien przyjąć rezygnację marszałka na najbliższej sesji,

1 Tekst jednolity: Dz. U. z 2019 r. poz. 512 z późn. zm.

2 Portal Samorządowy, Podlaskie: Artur Kosicki zrezygnował z funkcji marszałka, https://www.portalsamorzadowy.pl/polityka-i-spoleczenstwo/podlaskie-artur-kosicki-zrezygnowal-z-funkcji-marszalka,120826.html [dostęp: 27.08.2020 r.]. 
podejmując uchwałę o przyjęciu rezygnacji całego zarządu³. Ustawa wyraźnie bowiem stanowi, że sejmik województwa podejmuje uchwałę o przyjęciu rezygnacji całego zarządu, co oznacza, że złożenie rezygnacji przez marszałka województwa obliguje sejmik województwa do przyjęcia jego rezygnacji, jak również rezygnacji całego zarządu. Sejmik województwa nie ma innej możliwości, jak przyjęcie rezygnacji złożonej przez marszałka województwa. Jego rola nie polega bowiem na weryfikacji oświadczenia złożonego w przedmiocie rezygnacji, lecz na „stwierdzeniu”, że rezygnacja została skutecznie złożona. Słowo „przyjmuje”, którym posłużył się ustawodawca w art. 38 ust. 1 u.s.w., rozumieć należy jako „przyjąć coś do wiadomości, pogodzić się z czymś, uznać za bezsporne"4. Zgodnie z dyrektywą języka potocznego normie należy nadać takie znaczenie, jakie ma ona $\mathrm{w}$ języku potocznym $^{5}$. Za powyższą wykładnią dodatkowo przemawia treść art. 38 ust. 3 u.s.w. Niepodjęcie bowiem uchwały, o której mowa w art. 38 ust. 2 u.s.w., bez względu na przyczyny takiego stanu, jest równoznaczne z przyjęciem rezygnacji marszałka województwa z upływem ostatniego dnia miesiąca, w którym odbyła się sesja sejmiku, zwołana w celu jej przyjęcia. Sejmik województwa nie może zatem „zablokować” rezygnacji marszałka województwa. Innymi słowy, sejmik województwa nie tylko nie może podjąć uchwały o odmowie przyjęcia rezygnacji marszałka województwa z pełnionej funkcji (bo ustawa wyraźnie określa, jaka ma być treść uchwały sejmi$\mathrm{ku}$ - przyjęcie rezygnacji), ale również nie może bezterminowo „odsunąç” w czasie terminu jej podjęcia (sesji), ustawa precyzuje bowiem, że przyjęcie rezygnacji ma nastąpić na "najbliższej sesji sejmiku”, jak również określa skutki niepodjęcia uchwały $\mathrm{w}$ tym przedmiocie, $\mathrm{w}$ tym reguluje skutki o charakterze temporalnym (art. 38 ust. 3 u.s.w.). Sejmik województwa nie może również „odsunąć” w czasie samego wywołania skutków prawnych przez rezygnację marszałka województwa, tj. nie może określić samodzielnie, kiedy wywoła ona skutki prawne, okoliczność ta wynika bowiem z samej ustawy (art. 38 ust. 2 i 3 u.s.w.).

Art. 38 ust. 1 u.s.w., ani żaden inny przepis tej ustawy, nie przewiduje możliwości cofnięcia rezygnacji złożonej przez marszałka województwa. Nie budzi natomiast wątpliwości to, że skutki prawne wywołuje dopiero przyjęcie takiej rezygnacji przez sejmik województwa (art. 38 ust. 2 u.s.w.), chyba że skutki te są następstwem niepodjęcia uchwały o przyjęciu rezygnacji (art. 38 ust. 3 u.s.w.). Samo zatem złożenie rezygnacji przez marszałka województwa nie oznacza jeszcze, że następuje rozwiązanie z nim stosunku pracy, marszałek przestaje być organem administracji

3 Cz. Martysz, w: Ustawa o samorządzie województwa. Komentarz, red. B. Dolnicki, Warszawa 2012, teza 1 do art. 38.

4 Słownik Języka Polskiego, t. 2, red. M. Szymczyk, Warszawa 1984, s. 1040.

5 L. Morawski, Wykładnia w orzecznictwie sądów. Komentarz, Toruń 2002, s. 119. 
publicznej, nie ma prawa wydawania decyzji administracyjnych, przestaje być kierownikiem urzędu marszałkowskiego, na co słusznie zwrócono uwagę w piśmiennictwie ${ }^{6}$. Konfrontacja art. 38 u.s.w. z art. $202 \S 4$ czy też z art. $369 \$ 5$ ustawy z dnia 15 września 2000 r. - Kodeks spółek handlowych ${ }^{7}$ (dalej: K.s.h.) nie pozostawia wątpliwości, że rezygnacja członka zarządu spółki kapitałowej jest jednostronną czynnością prawną. Żaden przepis K.s.h. nie tylko bowiem nie uzależnia skuteczności rezygnacji od jej przyjęcia, ale też nie określa trybu postępowania będącego następstwem złożenia oświadczenia woli w tej sprawie, w szczególności nie obliguje spółki do przyjęcia rezygnacji. Brak takiej regulacji - przy założeniu dwustronnego charakteru omawianej czynności - pozbawia oświadczenie woli o rezygnacji waloru zdarzenia prawnego, stanowiącego samodzielną podstawę wygaśnięcia mandatu ${ }^{8}$. Skoro zatem w przypadku rezygnacji marszałka województwa z pełnionej funkcji dla jej skuteczności niezbędne jest podjęcie uchwały przez sejmik województwa, a ustawa określa tryb postępowania w przedmiocie podjęcia takiej uchwały (art. 38 ust. 1 i 2 u.s.w.), nie może budzić wątpliwości, że rezygnacja marszałka województwa ma na gruncie ustawy o samorządzie województwa charakter czynności dwustronnej, z zastrzeżeniem art. 38 ust. 3 u.s.w. Nie oznacza to, że oświadczenia marszałka województwa o rezygnacji z pełnionej funkcji jest prośbą, czy też wnioskiem zainteresowanego o odwołanie, ustawa o samorządzie województwa nie przewiduje bowiem żadnej podstawy prawnej do tego, aby sejmik mógł podjąć uchwałę o odmowie przyjęcia rezygnacji. Dwustronność ma bowiem w tym przypadku ograniczony charakter, bo to jedna strona - marszałek województwa - składa oświadczenie, które jest wiążące dla drugiej strony - sejmiku województwa, albowiem ustawa determinuje treść jego uchwały (przyjęcie rezygnacji). Złożenie rezygnacji, mimo swej skuteczności, która dotyczy samego oświadczenia woli, nie wywołuje automatycznie wskazanych powyżej skutków prawnych, obligując jedynie do umieszczenia w porządku obrad najbliższej sesji sejmiku punktu poświęconego przyjęciu rezygnacji marszałka województwa. Złożenie rezygnacji przez marszałka województwa uruchamia postępowanie w przedmiocie jej przyjęcia przez sejmik województwa, a do czasu podjęcia uchwały przez sejmik marszałek województwa pełni swoją funkcję na dotychczasowych zasadach, albowiem jego mandat nie doznaje żadnych ograniczeń. Nadal jest marszałkiem województwa, organem administracji publicznej oraz kierownikiem urzędu marszałkowskiego. Ustawodawca nie przewidział tu zatem żadnego automatyzmu odnośnie do

6 Cz. Martysz, w: Ustawa o samorządzie województwa..., teza 2 do art. 38.

7 Tekst jednolity: Dz. U. z 2019 r. poz. 505 z późn. zm.

8 Z. Kuniewicz, Rezygnacja jako przesłanka wygaśnięcia mandatu członka organu spółki kapitałowej, Studia Prawnicze 2007, nr 2, s. 33 i nast. 
wygaśnięcia mandatu marszałka województwa. Ustawodawca może ukształtować rezygnację jako czynność wywołującą skutek prawny z chwilą złożenia oświadczenia woli o rezygnacji albo też jako czynność, której skuteczność, rozumiana jako wywołanie zamierzonych skutków prawnych, uzależniona jest od przyjęcia tego oświadczenia ${ }^{9}$. W przypadku rezygnacji marszałka województwa ustawodawca wyraźnie wybrał to drugie rozwiązanie. Pierwsze znane jest prawu handlowemu, na co słusznie zwrócono uwagę w orzecznictwie, podkreślając, że rezygnacja jako jednostronna czynność prawna członka zarządu może nastąpić z dniem albo w terminie określonym w oświadczeniu o rezygnacji, nie wymagając przyjmowania przez organ spółki i podejmowania z jej strony jakichkolwiek czynności, od których zależałaby skuteczność rezygnacji ${ }^{10}$.

W piśmiennictwie wyrażono pogląd, że bez względu na to, kiedy rezygnacja zostanie złożona przez marszałka województwa, jej wycofanie przez uprawniony podmiot może nastąpić najpóźniej przed aktem głosowania w tej sprawie ${ }^{11}$. Podzielam to stanowisko. Do czasu bowiem głosowania w przedmiocie przyjęcia rezygnacji marszałka województwa jest on dysponentem złożonego przez siebie oświadczenia i może je wycofać. Nie ma tu znaczenia okoliczność, że żaden przepis ustawy o samorządzie województwa nie przyznaje mu takiego prawa. Nie jest to niezbędne, albowiem nie jest tak, że tylko w przypadku, gdy ustawa wyraźnie przewiduje możliwość cofnięcia oświadczenia woli, uprawniony podmiot jest do tego uprawniony. Prawo dysponowania złożonym oświadczeniem o rezygnacji wynika przede wszystkim z faktu, że jest ona aktem dobrowolnym, wyrażając wolę zaprzestania pełnienia funkcji ${ }^{12}$. Skoro istotą rezygnacji jest dobrowolność, to nie można pozbawić podmiotu uprawnionego do jej złożenia możliwości zmiany pierwotnej decyzji, gdy jego oświadczenie nie wywołało jeszcze zamierzonych początkowo skutków prawnych. $Z$ istoty dobrowolności przy składaniu danego oświadczenia wynika nie tylko możliwość ukształtowania jego treści, ale również dysponowanie złożonym oświadczeniem, chyba że z ustawy wynika, że samo złożenie oświadczenia wywołuje określone skutki prawne, będące następstwem jego treści. Odmienna interpretacja oznaczałaby, że dobrowolność złożenia rezygnacji ma w istocie ograniczony charakter, przyjmując postać oświadczenia definitywnego i nieodwoływalnego. Na gruncie art. 38 u.s.w. nie ma żadnych podstaw, aby twierdzić, że taki

9 Tamże.

10 M.in. wyrok SA w Krakowie z dnia 28 maja 2014 r., III AUa 534/12, LEX nr 1496423; wyrok NSA z dnia 20 października 2015 r., I GSK 264/14, LEX nr 1985613; wyrok SA w Krakowie z dnia 29 czerwca 2018 r., I Aga 144/18, LEX nr 2584520.

11 Cz. Martysz, w: Ustawa o samorządzie województwa..., teza 1 do art. 38.

12 Tamże, teza 1 do art. 38. 
właśnie charakter ma oświadczenie marszałka województwa o rezygnacji z pełnionej funkcji. Po pierwsze, przepis ten nie wyłącza możliwości cofnięcia oświadczenia o rezygnacji. Po drugie, $\mathrm{z}$ art. 38 ust. 1 i 2 u.s.w. nie wynika, że oświadczenie o rezygnacji ma charakter definitywny i nieodwoływalny. Gdyby taka była intencja ustawodawcy, oświadczenie marszałka województwa o rezygnacji miałoby charakter jednostronny, wywołując zamierzone skutki prawne przez sam fakt jego złożenia uprawnionemu organowi - sejmikowi województwa.

Za powyższą wykładnią przemawia argumentacja konstytucyjna. Jak stanowi art. 65 ust. 1 Konstytucji RP z dnia 2 kwietnia 1997 r. ${ }^{13}$, każdemu zapewnia się wolność wyboru i wykonywania zawodu oraz wyboru miejsca pracy, przy czym wyjątki określa ustawa. Jak wskazano w orzecznictwie, norma art. 65 ust. 1 Konstytucji RP $\mathrm{z}$ dnia 2 kwietnia $1997 \mathrm{r}$. z jednej strony wskazuje na powszechne prawo wyboru i wykonywania zawodu, z drugiej zaś statuuje, iż wyjątki od tej zasady winny być określone ustawowo. Tym samym jakiekolwiek ograniczenia w wykonywaniu zawodu winny w pierwszej kolejności wynikać z normy rangi ustawowej (a nie niższego rzędu), z drugiej - wyjątki takie powinny być sformułowane w sposób jednoznaczny i kategoryczny. Nie mogą być domniemywane, w razie wątpliwości zaś wykładnia takich wyjątków nie może mieć charakteru rozszerzającego. Niedopuszczalne jest tu także wprowadzanie ograniczeń w wykonywaniu zawodu czy to poprzez subdelegację, czy też poprzez wykorzystanie ogólnej normy kompetencyjnej ${ }^{14}$. Skoro Konstytucja gwarantuje wolność wyboru i wykonywania zawodu, to możliwość cofnięcia złożonej rezygnacji wpisuje się w istotę tej wolności. Uprawniony podmiot dzięki temu ma możliwość rzeczywistego dokonania wyboru, zmieniając pierwotną decyzję, która mogła być podjęta np. pod wpływem chwili, bez gruntownego rozważenia wszystkich argumentów za i przeciw, czy też być wyrazem określonego manifestu, który w danych okolicznościach miał sens, ale w okolicznościach zmienionych pozbawiony jest takiego znaczenia. Wykonywanie zawodu, o którym mowa w Konstytucji RP z dnia 2 kwietnia 1997 r., to także kontynuowanie dotychczasowej aktywności, wyrażające się dalszym pełnieniem funkcji mimo pierwotnie wyrażonej woli rezygnacji. Ustawodawca wykluczając automatyzm w zakresie wywołania skutków prawnych przez rezygnację marszałka województwa, stworzył warunki do tego, aby - w wyniku refleksji nad zaistniałą sytuacją - marszałek rozważył, czy jego pierwotna decyzja jest trafna, oddaje jego rzeczywistą wolę, jak również czy koresponduje z jego rzeczywistymi planami zawodowymi. Okres dzielący datę złożenia rezygnacji i datę sesji sejmiku województwa, podczas której ma być podęta uchwała

13 Dz. U. z 1997 r. Nr 78, poz. 483 z późn. zm.

14 Wyrok SA w Warszawie z dnia 29 listopada 2018 r., VI ACa 356/18, LEX nr 2695046. 
o jej przyjęciu, to czas, w którym marszałek województwa może, korzystając z konstytucyjnej wolności wyboru oraz wykonywania zawodu oraz wyboru miejsca pracy, ocenić, czy złożenie rezygnacji jest zasadne, czy też nie. Brak takiej możliwości w istocie odbierałby mu możliwość dochowania wierności przyjętemu na siebie zobowiązaniu odnośnie do pełnienia funkcji publicznej, jak również pozbawiałby możliwości dokonania wyboru odnośnie do miejsca pracy, bo nie mógłby on podjąć decyzji, że będzie jednak kontynuował wykonywanie swych obowiązków $\mathrm{w}$ ramach dotychczas pełnionej funkcji. Tylko w drodze ustawy możliwe jest wyłączenie takiej możliwości i przyjęcie, że akt rezygnacji nie podlega odwołaniu. Takie rozwiązanie, jak już wskazano, przyjęto w prawie handlowym. W takim przypadku ustawodawca rezygnację ujmuje jako czynność jednostronną, a zatem inaczej niż w na gruncie art. 38 ust. 1 u.s.w. Jak trafnie wskazano w piśmiennictwie, Konstytucja RP z dnia 2 kwietnia 1997 r. gwarantując wolność wyboru i wykonywania zawodu, zapewnia ochronę zarówno na etapie podejmowania pracy, jak i późniejszego jej wykonywania ${ }^{15}$. Właśnie wzgląd na ochronę „późniejszego wykonywania zawodu" przemawia za tym, aby uznać, że skoro ustawodawca nie uregulował rezygnacji marszałka województwa jako czynności jednostronnej, wywołującej skutki prawne przez sam fakt jej złożenia, to tym samym stworzył uprawnionemu do złożenia rezygnacji możliwość zmiany pierwotnej decyzji i w efekcie jej wycofania. W takim bowiem przypadku zagwarantowana jest wolność wykonywania zawodu na tym etapie, a dokładniej kontynuowania pełnienia danej funkcji. Podzielam pogląd, że człowiek powinien mieć swobodę (wolność) co do wyboru i kontynuowania wybranej aktywności zawodowej ${ }^{16}$. Skoro zaś tak, to nie można go pozbawić możliwości cofnięcia pierwotnego oświadczenia woli, jeżeli nie wywołało one jeszcze zamierzonych pierwotnie skutków prawnych, a zatem nie doprowadziło do żadnej zmiany. Trybunał Konstytucyjny zasadnie uznał, że art. 65 ust. 1 Konstytucji RP z dnia 2 kwietnia 1997 r. nakazuje ustawodawcy zapewnić możliwość wyboru zawodu i miejsca pracy oraz możliwość wykonywania zawodu w sposób wolny od zewnętrznej ingerencji, w możliwie najszerszym zakresie ${ }^{17}$. Ten możliwie najszerszy zakres oznacza - w analizowanym przypadku - stworzenie warunków do kontynuowania dotychczasowej aktywności, w sytuacji gdy uprawniony podmiot zmieni pierwotną decyzję o rezygnacji z pełnionej funkcji. Taka zmiana mieści się w swobodzie wyboru miejsca pracy, przy czym możliwość odwołania pierwotnego oświadczenia ograniczona została czasowo. Ustawa zakreśla bowiem ramy czasowe

15 A. Sobczyk, K. Kulig, w: Konstytucja RP, t. 1: Komentarz: art. 1-86, red. M. Safjan, L. Bosek, Warszawa 2016, s. 1469.

16 Tamże.

17 Wyrok TK z dnia 19 marca 2001 r., K 32/00, OTK 2001, nr 3, poz. 50. 
na ewentualną zmianę decyzji, w momencie bowiem przystąpienia do głosowania nad uchwałą o przyjęciu rezygnacji marszałka województwa przestaje być on dysponentem swego oświadczenia. Gdy dojdzie już do etapu głosowania, oświadczenie o rezygnacji nie może być cofnięte, rozpoczął się bowiem etap decyzyjny w jego przedmiocie, a to wyklucza jakikolwiek wpływ na jego treść ze strony podmiotu, który je złożył, jak również jakiegokolwiek innego podmiotu. Na tym etapie wyłącznie sejmik województwa jest uprawniony, a zarazem zobowiązany do podjęcia uchwały, przy czym ustawa wyraźnie określa, jaka ma być treść uchwały sejmiku - przyjęcie rezygnacji marszałka województwa. Tu nie ma pola na żadne wycofanie oświadczenia przez marszałka województwa, skoro jedyne, co może mieć miejsce, to przyjęcie rezygnacji. Zresztą na tym etapie procedowania przez sejmik województwa marszałek nie ma żadnej formalnej możliwości zajęcia stanowiska w sprawie własnej rezygnacji, jedyna czynność, jaka jest przeprowadzana, to głosowanie nad jej przyjęciem, co wyraźnie wynika z ustawy. Do tego momentu, tj. do głosowania, nic jeszcze nie jest przesądzone, skutki prawne rezygnacji jeszcze nie zaistniały, nie występuje zatem stan nieodwracalny, jak też nie sposób jest uznać, że doszło do jakiejkolwiek zmiany, a wycofanie rezygnacji doprowadziłoby do zakłócenia prawidłowego funkcjonowania samorządu województwa. Wręcz przeciwnie, do czasu przyjęcia rezygnacji marszałka województwa zarząd województwa funkcjonuje w dotychczasowym składzie, a ewentualne cofnięcie rezygnacji przez marszałka województwa usuwa element niepewności i umożliwia kontynuowanie jego działalności. Niepewność związana z koniecznością dokonania wyboru nowego zarządu województwa, w tym marszałka, będąca następstwem złożenia rezygnacji przez dotychczasowego marszałka, zostaje zakończona w sytuacji, w której odwoła on swe pierwotne oświadczenie. Można zatem uznać, że przyjęcie możliwości cofnięcia rezygnacji przez marszałka województwa jest elementem stabilizacji sytuacji w samorządzie województwa, a z tego punktu widzenia nie można uznać, że negatywnie wpływa ono na funkcjonowanie organów samorządu województwa. Tym samym instytucja cofnięcia rezygnacji przez marszałka województwa z jednej strony służy realizacji wolności, o której mowa w art. 65 ust. 1 Konstytucji RP z dnia 2 kwietnia 1997 r., a z drugiej nie zakłóca ona w żadnej mierze prawidłowego funkcjonowania samorządu województwa, tj. skorzystanie z takiej możliwości przez marszałka województwa nie powoduje żadnych ujemnych skutków.

Za zaprezentowaną wykładnią dodatkowo przemawia ujęcie instytucji rezygnacji marszałka województwa w ustawie o samorządzie województwa. Marszałek województwa składając rezygnację, nie jest zobowiązany do jej uzasadnienia. Nie musi zatem ujawnić motywów, które doprowadziły do podjęcia takiej decyzji. Oczywiście może to uczynić, ale nie jest do tego zobowiązany, motywy te zaś 
nie podlegają ocenie przez sejmik województwa. To zatem indywidualna decyzja marszałka województwa, która nie podlega weryfikacji przez sejmik województwa. Artykuł 38 ust. 1 u.s.w. wyraźnie zatem podkreśla pełną autonomię marszałka województwa przy podejmowaniu decyzji o rezygnacji. Sejmik województwa nad jego oświadczeniem nie przeprowadza żadnej debaty, nie podlega ona też opiniowaniu przez komisję rewizyjną czy też jakąkolwiek inną komisją sejmiku. Jest to zatem decyzja nie tylko dobrowolna, ale i niekontrolowalna, nieweryfikowalna w żadnym trybie. Wola marszałka województwa z punktu widzenia przywołanego przepisu ustawy o samorządzie województwa ma zatem wyłączne i decydujące znaczenie. Innymi słowy, ustawa o samorządzie województwa jedynie marszałkowi województwa pozostawia decyzję, czy będzie on kontynuował pełnienie funkcji, czy też nie, w pełni afirmując jego stanowisko. Oczywiście reguluje ona też tryb odwołania marszałka województwa (art. 37 ust. 1-4 u.s.w.), ale w tym przypadku wymaga uzasadnienia przyczyny odwołania i opinii komisji rewizyjnej (art. 37 ust. 2 u.s.w.). Nie można zatem utożsamiać instytucji rezygnacji marszałka województwa i jego odwołania, o czym będzie jeszcze mowa. W tym pierwszym przypadku decydujące znaczenie ma wola samego marszałka województwa, w drugim zaś - wola sejmiku województwa. Skoro w pierwszym przypadku uwzględnić należy wolę marszałka województwa, która nie może być zanegowana w żadnym trybie i w żadnych okolicznościach, to - w ramach jej uwzględnienia - należy dopuścić możliwość cofnięcia oświadczenia o rezygnacji z pełnionej funkcji. Dopóki wola marszałka województwa nie wywoła skutków prawnych, to jego oświadczenie ma wyłączne i decydujące znaczenie, zmiana zatem jego kierunku (rezygnacja cofnięcie rezygnacji) mieści się w ramach wyrażenia woli odnośnie do pełnienia funkcji i w związku $\mathrm{z}$ tym musi być uwzględniona. $\mathrm{Z}$ art. 38 ust. 1 u.s.w. wynika obowiązek poszanowania woli marszałka województwa, a zatem także zmiany jej pierwotnego kierunku. W obu bowiem przypadkach - rezygnacji i cofnięcia rezygnacji jest to wraz woli marszałka województwa. Tak jak sejmik województwa nie dysponuje prawem do ustalenia i weryfikacji przyczyn złożenia rezygnacji przez marszałka województwa, tak nie ma również możliwości zanegowania jego woli dalszego pełnienia swej funkcji. Ustawa nie przyznała sejmikowi województwa możliwości badania woli marszałka województwa, co dotyczy każdego jej przejawu, zarówno woli rezygnacji, jak i woli jej odwołania. Rola sejmiku województwa ma charakter reaktywny, przy czym reakcja dotyczy wyłącznie przypadku, w którym złożona została rezygnacja. Dopóki istnieje oświadczenie w jej przedmiocie, dopóty zastosowanie znajduje art. 38 ust. 1 i 2 u.s.w. jako wyraz uwzględnienia woli marszałka województwa. Brak takiego oświadczenia czyni procedowanie w przedmiocie przyjęcia rezygnacji marszałka województwa bezprzedmiotowym, 
nie ma bowiem rezygnacji, o której mowa w art. 38 ust. 1 u.s.w. Uwzględniając tę zależność, zasadne jest stanowisko, iż z art. 38 ust. 1 i 2 u.s.w. wynika konieczność uwzględnienia aktualnej woli marszałka województwa, co oznacza, że dopóki istnieje akt rezygnacji, dopóty sens ma procedowanie w przedmiocie jej przyjęcia. Skoro rezygnacja jest wyrazem woli marszałka województwa, to zmiana jego stanowiska oznacza, że finalnie rezygnacja nie została złożona i nie istnieje w sensie prawnym. Decydujące znaczenie dla istnienia rezygnacji ma bowiem wola marszałka, a zatem w sytuacji, gdy marszałek województwa cofnie oświadczenie o rezygnacji, to tym samym - ze względu na treść art. art. 38 ust. 1 i 2 u.s.w. - nie będzie przedmiotu postępowania sejmiku województwa. Sejmik województwa może jedynie uwzględnić wolę marszałka województwa, a zatem związany jest jej kierunkiem. Wola rezygnacji musi występować nie tylko w dacie jej złożenia (co oczywiste), ale także w dacie głosowania nad uchwałą o przyjęciu rezygnacji. Taki wniosek wynika $z$ art. 38 ust. 1 u.s.w. sejmik województwa nie może zatem uznać, że marszałek województwa nie może cofnąć swojej rezygnacji, nie ma bowiem żadnej kompetencji do oceny woli marszałka. Sejmik województwa nie może też ingerować w wolę marszałka i nie uwzględnić jej zmiany. Podstawy prawnej do tego brak, a organy władzy publicznej działają na podstawie i w granicach prawa (art. 7 Konstytucji RP z dnia 2 kwietnia 1997 r.).

Powyższych uwag nie podważa charakter prawny rezygnacji marszałka województwa. Instytucja ta regulowana jest przez prawo publiczne. Nie można jej jednak utożsamiać z wnioskiem o odwołanie marszałka województwa, który także regulowany jest przez prawo publiczne. W odniesieniu do wniosku o odwołanie starosty (analogicznie w przypadku marszałka województwa, uwzględniając charakter procedury odwołania marszałka województwa i starosty) w orzecznictwie przyjęto, że braku regulacji w zakresie możliwości cofania przez radnych oświadczeń woli (w tym przypadku wniosku o odwołanie starosty) nie można traktować jako luki prawnej, wydaje się on raczej wynikiem wielu uwarunkowań, w tym aksjologicznych, oraz potrzeby (której wyrazem są przepisy art. 31 ustawy z dnia 5 czerwca 1998 r. o samorządzie powiatowym ${ }^{18}$, dalej: u.s.p.) zapewnienia prawidłowego funkcjonowania organu kolegialnego - zarządu powiatu. Wskazano w nim również, że ustawodawca nie wypowiadając się w przedmiocie możliwości cofnięcia wniosku o odwołanie starosty uprzednio skutecznie złożonego przez grupę radnych, stanął na stanowisku, że z uwagi na skutki, jakie pociąga za sobą złożenie takiego wniosku, jego cofnięcie nie jest dopuszczalne, wymagane jest 
przeprowadzenie głosowania ${ }^{19}$. Ten sposób rozumowania podziela orzecznictwo administracyjne ${ }^{20}$. Wniosek o odwołanie starosty, jak również marszałka województwa wyraża wolę radnych (i z tego punktu widzenia stanowi oświadczenie woli radnych), ale jest to oświadczenie o charakterze postulatywnym (co wynika $\mathrm{z}$ charakteru wniosku) i jako takie uruchamia procedurę w przedmiocie odwołania starosty i marszałka województwa. Wola ta ma znaczenie dla wszczęcia tego postępowania, natomiast jego wynik związany jest $\mathrm{z}$ oceną zasadności wniosku przez organ stanowiący. Samo złożenie takiego wniosku wywołuje określone skutki o charakterze publicznoprawnym, które wprawdzie nie odnoszą się do statusu starosty czy też marszałka województwa, ale dotyczą funkcjonowania samorządu powiatowego i wojewódzkiego. Ustawa określa, iż odwołanie starosty następuje w głosowaniu tajnym, większością co najmniej 3/5 ustawowego składu rady powiatu (art. 31 ust. 3 u.s.p.) i taki sam tryb obowiązuje także w przypadku wniosku o odwołanie marszałka województwa (art. 37 ust. 3 u.s.w.). Wynika z tego, że w przypadku wniosku o odwołanie wola wnioskodawców nie jest decydująca, muszą oni bowiem przekonać kwalifikowaną większość członków rady powiatu czy też sejmiku województwa do zasadności odwołania starosty lub marszałka województwa. Jeżeli wniosek nie uzyska poparcia większości wymaganej przez ustawę, kolejny wniosek o odwołanie może być zgłoszony nie wcześniej niż po upływie 6 miesięcy od poprzedniego głosowania (31 ust. 3 u.s.p. oraz art. 37 ust. 3 u.s.w.). W przypadku wniosku o odwołanie starosty oraz marszałka województwa radni składający taki wniosek nie są jego dysponentami, ich rola ogranicza się bowiem do zainicjowania właściwego postępowania i na tym się ona kończy (jako wnioskodawców). Wniosek o odwołanie starosty i marszałka województwa jest faktem prawnym, który zaistniał w określonym czasie ( $w$ dacie jego złożenia), przy czym jego złożenie wywołuje podstawowy skutek prawny w postaci obowiązku jego rozpoznania przez właściwy organ - radę powiatu czy też sejmik województwa, przy zachowanie właściwej, ściśle określonej przez ustawę procedury. W tym wypadku można mówić o rozpoznaniu wniosku, albowiem wnioskodawcy zobowiązani są do jego uzasadnienia, kierunek uchwały zaś nie jest determinowany przez ustawę, lecz jest następstwem oceny, której dokonuje organ stanowiący. Samo bowiem złożenie wniosku o odwołanie starosty lub marszałka województwa nie oznacza, że rada powiatu lub sejmik województwa zobowiązane są podjąć uchwałę zgodną z wolą wnioskodawców. Innymi słowy, złożenie wniosku o odwołanie uruchamia zatem postępowanie, którego wynik zależy od głosowania, rola rady powiatu czy też sejmiku

19 Wyrok WSA w Gorzowie Wielkopolskim z dnia 1 września 2016 r., II SA/Go 504/16, LEX nr 2104759.

20 M.in. rozstrzygnięcie nadzorcze Wojewody Lubuskiego Nr NK-I.4131.136.2016.TDom. 
województwa zaś jest decyzyjna, a nie „potwierdzająca”, co wyraźnie wynika z ustawy. Istotne jest przy tym to, że wnioskodawca i decydent to różne podmioty. Wprawdzie wniosek o odwołanie starosty i marszałka województwa mogą złożyć wyłącznie radni (art. 31 ust. 1 u.s.p. i art. 37 ust. 1 u.s.w.) i wchodzą oni w skład organu, który decyduje w przedmiocie odwołania starosty i marszałka województwa, nie ma przy tym ustawowego ich wyłączenia od głosowania, ale wola wnioskodawców nie jest równoznaczna $\mathrm{z}$ wolą rady powiatu czy też sejmiku województwa. Tylko bowiem rada powiatu lub sejmik województwa, po uzyskaniu wymaganej przez ustawę większości, mogą odwołać starostę lub marszałka województwa. Argumentacja wnioskodawców może być podzielona przez radę powiatu lub sejmik województwa, ale tak być nie musi. Są to bowiem w sensie prawnym różne podmioty, mimo że z punktu widzenia osobowego może tu wystąpić zbieżność. Decydujące znaczenie ma wola większości rady powiatu i sejmiku województwa, która to większość musi przybrać postać kwalifikowaną. W przypadku złożenia rezygnacji marszałka województwa (analogicznie także i starosty) decydujące znaczenie ma wola rezygnującego, albowiem rola sejmiku województwa (odpowiednio rady powiatu) nie polega na rozstrzygnięciu o jej zasadności (jak w przypadku wniosku o odwołanie), lecz na „przyjęciu”, przy czym niepodjęcie uchwały o przyjęciu rezygnacji nie zapobiegnie wywołaniu skutków prawnych przez oświadczenie o rezygnacji (art. 38 ust. 3 u.s.w.). Inaczej rzecz ujmując, złożenie oświadczenia przez starostę lub marszałka województwa jest wiążące dla organu stanowiącego ${ }^{21}$. Rezygnacja marszałka województwa jest zatem aktem o charakterze samoistnym, niezależnym od oceny zasadności jej złożenia przez sejmik województwa. Głosowanie sejmiku województwa nie może zanegować woli rezygnującego. Wprawdzie rezygnujący i podmiot „przyjmujący” rezygnację to dwa różne podmioty, ale w przypadku wniosku o odwołanie ustawa wyraźnie określa tryb postępowania, w tym sekwencję czynności, które są następstwem złożenia takiego wniosku. Ustawowa regulacja dotycząca wniosku o odwołanie starosty i marszałka województwa oraz postępowania w jego przedmiocie (określenie minimalnej liczby radnych, którzy mogą wystąpić z takim wnioskiem, wymóg pisemności i uzasadnienia, wymóg zaopiniowania przez komisję rewizyjną, zakaz przeprowadzania głosowania nad wnioskiem wcześniej niż po upływie miesiąca od złożenia wniosku) ma charakter zupełny i nie ma w tym trybie żadnej możliwości cofnięcia złożonego wniosku, jak również wycofania podpisów złożonych pod wnioskiem ${ }^{22}$. Inaczej jest w przypadku rezygnacji

21 M. Kotulski, w: Komentarz do ustawy o samorzadzie powiatowym, red. P. Chmielnicki, Warszawa 2005, s. 203. 
marszałka województwa (analogicznie starosty). W tym przypadku nie wprowadzono żadnych regulacji ściśle determinujących bieg postępowania po złożeniu takiego oświadczenia, z których wynikałoby, że nie jest możliwe cofnięcie rezygnacji, tj. brak jest przepisów, z których wynikałoby, że takie oświadczenie jest niedopuszczalne. Nie tylko nie ma wyraźnego przepisu zakazującego cofnięcia rezygnacji przez marszałka województwa, ale również nie wprowadzono przepisów, które ze względu na przyjęty tryb postępowania wykluczałyby cofnięcie złożonej rezygnacji. W przypadku wniosku o odwołanie starosty i marszałka województwa minimalna liczba radnych, którzy mogą złożyć wniosek o odwołanie, odnoszona jest do daty złożenia wniosku, a nie później, ich wola zaś ma charakter inicjatywny, a nie decyzyjny, co potwierdza dalsza procedura - opiniowanie, wymagany upływ czasu od złożenia wniosku i finalnie głosowanie nad jego zasadnością. Ustawa nie stwarza na żadnym etapie możliwości cofnięcia złożonego wniosku, czy też poszczególnych podpisów, bo wyraźnie określono, jakie czynności są podejmowane, kolejne etapy zaś ściśle powiązane są z poprzednimi. Gdyby ustawodawca dopuszczał możliwość cofnięcia wniosku lub poszczególnych podpisów, nie przyjąłby takiego biegu postępowania, wymagając na każdym kolejnym etapie ustalenia, czy istnieje wniosek o odwołanie marszałka województwa (analogicznie starosty). Takiego badania się jednak - zgodnie z ustawą - nie przeprowadza, wniosek o odwołanie - jeżeli spełnia wymogi ustawowe - wywołuje bowiem skutki prawne (a więc jest skuteczny) i do końca procedury stanowi on podstawę podejmowania dalszych czynności. Zgodnie z ustawą wyznacza on ramy dalszego postępowania, przy czym kontrola spełnienia wymogów formalnych dokonywana jest na dzień złożenia wniosku. Taki wniosek wynika z art. 37 ust. 1 i 2 u.s.w. Skoro bowiem wniosek co najmniej $1 / 4$ ustawowego składu sejmiku podlega zaopiniowaniu przez komisję rewizyjną (art. 37 ust. 2 u.s.w.), to nie może budzić wątpliwości, że komisja opiniuje, a ściślej jest zobowiązana zaopiniować, złożony wniosek. Odnosi się zatem do pisma radnych, które zostało złożone jako wniosek o odwołanie marszałka województwa. Komisja rewizyjna nie ma innej możliwości, jak sformułowanie opinii o tym wniosku (a nie jakimkolwiek innym). Nie może postępowania umorzyć - ustawa o samorządzie województwa nie zna takiej instytucji, ani też nie może wniosku pozostawić bez rozpoznania, także bowiem i takiej instytucji ustawa o samorządzie województwa nie reguluje. Z kolei głosowanie w sprawie odwołania marszałka województwa sejmik województwa przeprowadza po zapoznaniu się z opinią komisji rewizyjnej, a więc po zapoznaniu się z opinią dotyczącą wniosku o odwołanie marszałka województwa, który został złożony w trybie art. 37 ust. 1 u.s.w. Sekwencja wskazanych czynności jest logiczna, kolejne etapy nawiązują do etapu wcześniejszego, przy czym etap następny musi się odbyć, albowiem bieg postępowania nie 
może być - zgodnie z ustawą - zakończony na jednym z tych etapów, finalnie w każdym przypadku musi bowiem dojść do głosowania nad odwołaniem marszałka województwa. Taki jest przebieg i finał postępowania w przedmiocie odwołania marszałka województwa. Jedynie w przypadku jego śmierci w trakcie tego postępowania dalszych etapów się nie przeprowadza, nie dochodzi zatem do głosowania nad jego odwołaniem, nie ma już bowiem kogo odwołać, albowiem mandat marszałka wygasł wraz z jego śmiercią. Rezygnacja marszałka województwa nie jest wnioskiem, nie ma charakteru postulatywnego, co wyraźnie wynika $\mathrm{z}$ art. 38 ust. 1 u.s.w. Jej złożenie prowadzi do zwołania sesji sejmiku województwa, podczas której ma być przyjęta (nie jest możliwe jej nieprzyjęcie), ale ustawa nie przewiduje odniesienia się przez sejmik województwa do oświadczenia z daty jego złożenia, ale do stanu aktualnego. Przyjmuje się bowiem oświadczenie, które istnieje w momencie podejmowania uchwały. Rezygnacja musi zatem istnieć w dacie głosowania, jej brak zaś wyklucza podjęcie uchwały przez sejmik województwa. Odmienna interpretacja nie znajduje umocowania w treści art. 38 ust. 1 i 2 u.s.w. Wniosek o odwołanie marszałka województwa (analogicznie starosty), ze względu na jego istotę i charakter, jak również przyjętą procedurę odnoszącą się do jego rozpoznania, jest skuteczny, jeżeli spełniono wymogi, o których mowa w art. 37 ust. 1 i 2 u.s.w., i jako taki podlega rozpoznaniu. $W$ tym wypadku wola raz wyrażona jest ostateczna, jej zmiana zaś przez radnych, który poparli wniosek, może skutkować brakiem poparcia wniosku, a nie jego cofnięciem czy też cofnięciem podpisów przez poszczególnych radnych, złożonych pod wnioskiem. Radny nie jest zatem pozbawiony możliwości zmiany swej pierwotnej decyzji (o poparciu wniosku o odwołanie marszałka województwa), tyle tylko, że następuje to poprzez brak poparcia dla złożonego już (skutecznie) wniosku. Skuteczność wniosku o odwołanie marszałka województwa (analogicznie starosty) związana jest ze spełnieniem wymogów formalnych, o których mowa w art. 37 ust. 1 i 2 u.s.w. Skuteczność rezygnacji przez marszałka województwa związana jest $\mathrm{z}$ wyrażeniem (istnieniem) woli zaprzestania pełnienia dotychczasowej funkcji, czego finałem jest jej przyjęcie przez sejmik województwa. W przypadku wniosku o odwołanie marszałka województwa sejmik nie odnosi się do woli radnych, lecz do złożonego przez nich wniosku i to ten wniosek wyznacza ramy ich procedowania. Wola radnych jest podstawą do sformułowania wniosku, ale po jego złożeniu zgodnie z ustawą, to on stanowi punkt odniesienia, a ściślej argumentacja w nim zawarta. Różnica między wskazanymi instytucjami jest więc wyraźna - w przypadku rezygnacji marszałka województwa sejmik przyjmuje jego oświadczenie, co oznacza, że zmiana jego kierunku wyklucza możliwość podjęcia uchwały w tym przedmiocie (jest zatem bezprzedmiotowe), w przypadku wniosku o odwołanie sejmik ocenia zaś, czy argumenty podane we wniosku (zawarte w jego 
uzasadnieniu) przemawiają za zakończeniem pełnienia funkcji przez marszałka województwa (są na tyle przekonujące, że zasadne jest odwołanie marszałka województwa). W tym pierwszym wypadku sejmik stwierdza zatem de facto, że wolą marszałka jest zakończenie pełnienia funkcji (a co za tym idzie, bez takiej woli sejmik uchwały o przyjęciu rezygnacji podjąć nie może - art. 38 ust. 1 i 2 u.s.w.), a w tym drugim rozstrzyga, czy zachodzą podstawy do jego odwołania. Nie „stwierdza" zatem woli radnych w przedmiocie odwołania marszałka województwa, wola ta była bowiem niezbędna do zainicjowania samego postępowania, na etapie głosowania zaś odbyła się ocena, czy argumenty zawarte we wniosku są przekonujące dla radnych i przemawiają za odwołaniem marszałka. W obu przypadkach - rezygnacji marszałka województwa oraz jego odwołania - skutek jest ten sam - brak organu wykonawczego i obowiązek jego wyboru przez organ stanowiący ${ }^{23}$, ale różnica dotyczy przede wszystkim charakteru oświadczenia, które inicjuje postępowanie sejmiku województwa, jak również różna jest rola w obu postepowaniach organu stanowiącego województwa.

Podsumowując: marszałek województwa może złożyć na podstawie art. 38 ust. 1 u.s.w. rezygnację z pełnionej funkcji. Mimo że ustawa o samorządzie województwa nie przewiduje wyraźnie możliwości cofnięcia złożonej rezygnacji, przeprowadzone rozważania pozwalają na sformułowanie wniosku, że jest to możliwe do czasu rozpoczęcia głosowania przez sejmik nad uchwałą w przedmiocie przyjęcia rezygnacji marszałka województwa. W takim przypadku sejmik województwa nie może przyjąć rezygnacji marszałka województwa, ta bowiem w dacie głosowania już nie istnieje, dalsze postępowania w tej materii jest zatem bezprzedmiotowe.

\section{Bibliografia}

Komentarz do ustawy o samorzadzie powiatowym, red. P. Chmielnicki, Warszawa 2005.

Konstytucja RP, t. 1: Komentarz: art. 1-86, red. M. Safjan, L. Bosek, Warszawa 2016.

Kuniewicz Z., Rezygnacja jako przesłanka wygaśnięcia mandatu członka organu spółki kapitałowej, Studia Prawnicze 2007, nr 2.

Morawski L., Wykładnia w orzecznictwie sąów. Komentarz, Toruń 2002.

Słownik Języka Polskiego, t. 2, red. M. Szymczyk, Warszawa 1984.

Ustawa o samorzadzie województwa. Komentarz, red. B. Dolnicki, Warszawa 2012.

23 M. Kotulski, w: Komentarz do ustawy..., s. 227. 
